\title{
Level of Patient Satisfaction in Dental Hospital of Universitas Jember in December 2019 - February 2020
}

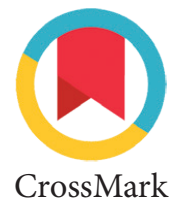

\author{
Dwi Prijatmoko, ${ }^{1 *}$ Elyda AA. Misrohmasari, ${ }^{2 *}$ Windy N. Eriyati ${ }^{3 *}$
}

\section{Abstract}

Objective: This study aims to determine the level of patient satisfaction at Universitas Jember Dental Hospital in December 2019 February 2020 based on patient status (clinic dental students' patients and dentists' patients). Dental Hospital Universitas Jember is one service provider that focuses on dental and oral health. Patients satisfaction is a result of comparing the services obtained with the patient's expectations. The level of patient satisfaction is important for Dental Hospital Universitas Jember to improve service performance.
Material and Methods: The study is a descriptive observational with cross sectional approach. Patients satisfaction was measured by Community Satisfaction Index (CSI) that consists of 14 indices.

Results: Patient satisfaction score was 73.424 for clinic dental students' patients and 76.917 for dentists' patients. Both scores were categorized as a good level of satisfaction.

Conclusion: Clinic dental students' patients and dentists' patients were satisfied with the service at Dental Hospital Universitas Jember.
${ }^{1}$ Department of Orthodontics, Faculty of Dentistry, Universitas Jember, Indonesia

${ }^{2}$ Department of Dental Public Health, Faculty of Dentistry, Universitas Jember, Indonesia

${ }^{3}$ Faculty of Dentistry, Universitas Jember, Indonesia
*Correspondence to: Dwi Prijatmoko, Elyda AA. Misrohmasari, Windy N. Eriyati, Department of Orthodontics, Faculty of Dentistry, Universitas Jember, Indonesia. Department of Dental Public Health, Faculty of Dentistry, Universitas Jember, Indonesia. Faculty of Dentistry, Universitas Jember, Indonesia gawat_76.fkg@unej.ac.id

Received: 28 July 2020

Revised: 4 December 2020 Accepted: 11 July 2021

Available Online: 1 August 2021

Keywords: Community Satisfaction Index (CSI), Patient's satisfaction

Cite this Article: Prijatmoko D, Misrohmasari EAA, Eriyati WN. 2021. Level of Patient Satisfaction in Dental Hospital of Universitas Jember in December 2019 - February 2020. Journal of Dentomaxillofacial Science 6(2): 106-109. D0I: 10.15562/jdmfs.v6i2.1077

\section{Introduction}

Dental Hospital Universitas Jember is organizes dental and oral health services are also used as a learning process infrastructure, education and research of dental health workers and other health professionals. Dental Hospital Universitas Jember is one of education in which this hospital provides dental and oral health services as well as functions as learning facility. ${ }^{1}$ Patients who come to this hospital are brought by dental students underdoing co-assistant programs (clinic dental students' patients) and general patients who come voluntarily by themselves (dentists' patients).

One of the key factors for success in improving health services through organizational performance begins with patient satisfaction. ${ }^{2}$ Patient satisfaction is the comparison of the services received by patients and the expected services. ${ }^{3}$ Patients will feel satisfied if the patient's expectations are met. ${ }^{4}$ On the other hand, patients will feel dissatisfied if the services do not meet the expectations, which will lead to complaints.

The level of patient satisfaction can be measured using the Community Satisfaction Index (CSI). CSI is data and information about the level of community satisfaction obtained from quantitative and qualitative measurements of public opinion in accessing services. This index of satisfaction covers 14 aspects, such as service procedures, service requirements, clarity of personnel, the discipline of personnel, responsibilities of personnel, the ability of personnel, speed of service, fairness of service, politeness and friendliness of personnel, reasonable service costs, the certainty of service costs, certainty of service schedules, environmental comfort, and environmental safety. The index can be used to measure the satisfaction of health service users.

Patient satisfaction is important for any hospital enabling them to improve and evaluate their quality-of-service performance. Patients who are satisfied with the services provided will likely seek the same services from the same facility. Therefore, this research aims to identify the level of patient satisfaction in Dental Hospital of the Universitas Jember in December 2019 - February 2020 both in clinic dental student' patients and dentist' patients.

\section{Material and Methods}

This research is a descriptive observational with a cross-sectional approach. It was conducted in the Dental Hospital Universitas Jember in Sumbersari Subdistrict, Jember District. The research was conducted in December 2019 - February 2020.

The research used a purposive sampling method involving 100 respondents. The selected respondents were patients in the general dental clinic, specialist dental clinic, dental conservation clinic, prosthodontia, oral disease clinic, periodontia, and oral surgery clinic of Dental Hospital Universitas Jember, who had been treated according to the criteria. 
Data were counted in each checklist. The checklist used a Likert scale with four choices adjusted to each indicator. The score was 1-4. The score was counted using the Community Satisfaction Index (CSI) table 1.

The CSI value is calculated by calculating the value of the aspects multiplied by 0.071 . Calculation

\begin{tabular}{lccc} 
Table 1 & \multicolumn{3}{c}{$\begin{array}{c}\text { The CSI interval value, CSI conversion value, and category } \\
\text { of service performance }\end{array}$} \\
$\begin{array}{lccc}\text { Perception } \\
\text { Score }\end{array}$ & $\begin{array}{c}\text { CSI Interval } \\
\text { Value }\end{array}$ & $\begin{array}{c}\text { CSI Conversion } \\
\text { Value }\end{array}$ & $\begin{array}{c}\text { Category of Service } \\
\text { Performance }\end{array}$ \\
\hline 1 & $1.00-1.75$ & $25-43.75$ & Very Poor \\
2 & $1.76-2.50$ & $43.76-62.50$ & Poor \\
3 & $2.51-3.25$ & $62.51-81.25$ & $\begin{array}{c}\text { Good } \\
4\end{array}$ \\
$3.26-4.00$ & $81.26-100.00$ & Excellent \\
\hline
\end{tabular}

Table 2 General characteristics of respondents

\begin{tabular}{|c|c|c|c|c|}
\hline Karakteristik & & Frequency & $\%$ & Total \% \\
\hline \multirow{2}{*}{ Gender } & Female & 82 & 82.0 & \multirow{2}{*}{100} \\
\hline & Male & 18 & 18.0 & \\
\hline \multirow{5}{*}{ Age } & $17-25$ & 83 & 83.0 & \multirow{5}{*}{100} \\
\hline & $26-35$ & 3 & 3.0 & \\
\hline & $36-45$ & 5 & 5.0 & \\
\hline & $46-55$ & 6 & 6.0 & \\
\hline & $56-65$ & 3 & 3.0 & \\
\hline \multirow{7}{*}{ Profession } & College student & 74 & 74.0 & \multirow{7}{*}{100} \\
\hline & Housewife & 8 & 8.0 & \\
\hline & Entrepreneur & 6 & 6.0 & \\
\hline & Laborers & 4 & 4.0 & \\
\hline & Unemployment & 4 & 4.0 & \\
\hline & Civil servants & 3 & 3.0 & \\
\hline & Not filled & 1 & 1.0 & \\
\hline \multirow{6}{*}{$\begin{array}{l}\text { Education } \\
\text { background }\end{array}$} & $\begin{array}{l}\text { Elementary } \\
\text { school }\end{array}$ & 4 & 4.0 & \multirow{6}{*}{100} \\
\hline & Middle school & 2 & 2.0 & \\
\hline & High school & 80 & 80.0 & \\
\hline & Diploma & 2 & 2.0 & \\
\hline & Bachelor & 10 & 10.0 & \\
\hline & Not filled & 2 & 2.0 & \\
\hline \multirow{2}{*}{ Old/New Patient } & Old & 87 & 87.0 & \multirow{2}{*}{100} \\
\hline & New & 13 & 13.0 & \\
\hline \multirow{3}{*}{ Length of visit } & $1-5$ & 87 & 87.0 & \multirow{3}{*}{100} \\
\hline & $6-10$ & 9 & 9.0 & \\
\hline & $11-15$ & 4 & 4.0 & \\
\hline \multirow{2}{*}{$\begin{array}{l}\text { Patient Status (clinic } \\
\text { dental students' } \\
\text { patient/dentists'- } \\
\text { patient) }\end{array}$} & $\begin{array}{l}\text { Clinic dental } \\
\text { students' patient }\end{array}$ & 82 & 82.0 & \multirow{2}{*}{100} \\
\hline & Dentists' patient & 18 & 18.0 & \\
\hline
\end{tabular}

of the 14 indicators used the formula of CSI = service unit $\mathrm{x} 25$ for interpretation. Then, the result of satisfaction with performance was determined as follows. $^{5}$

\section{Results}

Distribution of general characteristics of patients in the Dental Hospital Universitas Jember in December 2019 - February 2020 can be seen below.

Table 2 showed that the majority of respondents in this study were female, accounting for $82 \%$. There were $83 \%$ of respondents aged between $17-25$ years old. The majority of respondents were college students (74\%) and mostly graduated from highschools (80\%). The majority visited Dental Hospital Universitas Jember ranged from 1-5 visits (87\%) and mostly were clinic dental student' patients, which was $82 \%$ of respondents.

Assessment of patient satisfaction on performance in table 3 showed that dentists' patients consider the service performance into two categories, good and excellent. The data showed that the clarity of personnel, responsibilities of personnel, fairness of services, politeness, and friendliness of personnel were considered very good by the dentists' patients, while the other aspects were considered good. Assessment of service performance by dental students' patients showed excellent and good categories, excluding three aspects with poor category, namely discipline of personnel, speed of service, and certainty of service schedules.

Table 4 showed the result obtained from calculating each service aspect. Dentist' patients get a higher value than clinic dental student' patients. The results showed that dentist' patients get CSI values of service performance and the conversion interval was better than clinic dental students' patients which were 3.076 and 76.917

\section{Discussion}

The study showed that all 14 aspects considered in the good category of dentists' patients, while on the clinic dental students' patients, there are three aspects in the poor category. The aspects with good and excellent categories for both dental students' patients and dentists' patients are service procedures, service requirements, clarity of personnel, responsibilities of personnel, the ability of personnel, fairness of services, politeness, and friendliness of personnel, reasonable service cost, the certainty of service cost, environmental comfort, and environmental safety. On the other hand, the three aspects with the poor category are the discipline of personnel, speed of service, and certainty of service schedules. 
Table 3 Assessment of patient satisfaction in Dental Hospital Universitas Jember on services performance and Community Satisfaction Index (CSI) values

\begin{tabular}{|c|c|c|c|c|c|}
\hline \multirow[b]{2}{*}{ No } & \multirow[b]{2}{*}{ Aspects of service } & \multicolumn{2}{|c|}{ Value of aspects of service } & \multicolumn{2}{|c|}{ Category } \\
\hline & & $\begin{array}{c}\text { Dental students' } \\
\text { patients }\end{array}$ & $\begin{array}{l}\text { Dentists' } \\
\text { patients }\end{array}$ & $\begin{array}{c}\text { Dental students' } \\
\text { patients }\end{array}$ & $\begin{array}{l}\text { Dentists' } \\
\text { patients }\end{array}$ \\
\hline 1 & Service procedures & 3.01 & 3.11 & Good & Good \\
\hline 2 & Service requirements & 3. 07 & 3.27 & Excellent & Excellent \\
\hline 3 & Clarity of personnel & 2.91 & 3.05 & Good & Good \\
\hline 4 & Discipline of personnel & 2.42 & 2.61 & Poor & Good \\
\hline 5 & Responsibilities of personnel & 3.14 & 3.38 & Good & Excellent \\
\hline 6 & Ability of personnel & 3.12 & 3.16 & Good & Good \\
\hline 7 & Speed of service & 2.41 & 2.61 & Poor & Good \\
\hline 8 & Fairness of service & 3.31 & 3.44 & Excellent & Excellent \\
\hline 9 & Politeness and friendliness of personnel & 3.30 & 3.38 & Excellent & Excellent \\
\hline 10 & Reasonable service costs & 3.10 & 3.11 & Good & Good \\
\hline 11 & The certainty of service costs & 2. 98 & 3.22 & Good & Good \\
\hline 12 & The certainty of service schedules & 2. 39 & 2.77 & Poor & Good \\
\hline 13 & Environmental comfort & 2. 97 & 3.11 & Good & Good \\
\hline 14 & Environmental safety & 3.17 & 3.05 & Good & Good \\
\hline
\end{tabular}

Table 4 CSI interval values, CSI conversion values, category of service performance

\begin{tabular}{|c|c|c|}
\hline $\begin{array}{l}\text { Service and Patient } \\
\text { Satisfaction }\end{array}$ & Dental students' patients & Dentists' patients \\
\hline CSI Interval Values & 2.937 & 3.076 \\
\hline CSI Conversion Values & 73.424 & 76.917 \\
\hline $\begin{array}{l}\text { Category of Service } \\
\text { Performance }\end{array}$ & Good & Good \\
\hline Patient Satisfaction & Satisfied & Satisfied \\
\hline
\end{tabular}

Patients are satisfied with the service procedure and service requirements. It indicates that patients feel the service procedure and service requirements are easy and simple. Based on the result of observations, there are charts listed on the walls of Dental Hospital Universitas Jember and nurses who are ready to lead patients when receiving the services. The students always guide their patients and the dentists' patients are always guided by service personnel. Therefore, these patients feel the flow of procedures and requirements are easy.

Further, the patients also feel satisfied with the aspect of clarity of personnel and responsibility of personnel as the personnel is always available. Based on the observations, service personnel always direct patients from the beginning until the end of the service.

Patients assess that the ability and skills of personnel in providing services are good, and they feel satisfied with these aspects. It is in line with the result of the previous research regarding the patients' satisfaction on panoramic radiographic services at Dental Hospital Maranatha. ${ }^{6}$ The medical personnel's skill in communicating with patients in providing information on the provided or offered treatment highly influences the patient satisfaction. ${ }^{7,8}$

Regarding the aspect of the fairness of service, patients feel that they have been given services according to the standard (the first-come, the first to get service) and not based on their economic background. Based on the observation, patients receive the same service; for example, they get their turn to receive service based on their arrival time.

Patients are satisfied with the aspect of politeness and friendliness of personnel. The service personnel at Dental Hospital Universitas Jember have been trained to provide services to the community in polite and friendly ways. The staff's responsiveness can influence patient satisfaction in providing services such as their friendliness. The attitude shown by the behavior should meet the norms foreseen by the public, especially by the patient and the patient's family. ${ }^{8,9}$

Moreover, patients also feel satisfied with the aspect of the reasonable service cost and certainty of service cost. Based on the observation, the cost of service at Dental Hospital Universitas Jember is not much different from that of other clinics. Dentists' patients feel that the cost of service at Dental Hospital Universitas Jember is reasonable and certain. The students cover patient's costs either some or all. It means they get cheaper costs or even get the service for free. 
The aspect of environmental comfort and environmental safety is also considered good. The patient is satisfied with the waiting room and comfortable dental chair. A comfortable hospital environment (physical appearance) showed a positive and significant influence against patient's satisfaction. Indicating that the dimension of comfort (physical appearance) or comfortable hospital environment is the most influential dimensions and is associated with the quality of service perceived. ${ }^{9}$

Three aspects that are considered good by dentists' patients, but they are considered poor by the dental students' patients are the discipline of personnel, the speed of service, and the certainty of the service schedule. These three aspects are closely related to each other because they deal with the time of service.

Patients feel less satisfied with the discipline of the service personnel because they do not arrive on time. Work discipline can also be interpreted as an attitude of respect and obedience to the workplace's rules and regulations to provide satisfying services for patients. In other words, it will create good quality of services following the patients' expectation. ${ }^{10}$

Then, patients feel less satisfied with the speed of service. Based on the observation, it is because dentist patients are directly served by personnel without a long queue, while clinic dental students' patients have to wait because the students' dental chairs are alternately. This is related to the certainty of the service schedule. Based on observation, the schedule's certainty is less certain because there are patients who must go home before being treated and wait too long in the waiting room.

The total CSI value of all aspects for service performance at the Dental Hospital of the Universitas Jember is 73.424 for clinic dental students' patients and 76.917 for dentists' patients and considered in the good category. It indicates that the patients are satisfied with the service performance provided by the service personnel. Satisfaction is defined as the response of patients in receiving dental and oral health services toward the expected service performance after receiving the service. ${ }^{3}$

\section{Conclusion}

Based on the CSI calculations, this study indicates that patients consider the service performance of Dental Hospital of Universitas Jember in the good category so that the clinic dental student' patients and dentist' patients are satisfied with the service performance.

\section{Acknowledgment}

None.

\section{Conflict of Interest}

The authors report no conflict of interest.

\section{References}

1. Herwanda, Putra ED and Putri LY. The effect of perceived quality patient to revisit interest of oral and dental health service in Dental and Oral Hospital Unsyiah. Cakradonya Dent J 2017;9: 73-77.

2. Febri FR, Indrayanto A, Siswandari W. Quality performance of UNSOED Dental Education Hospital based on the criteria of malcolm baldrige. ICORE 2019;5: 280-287.

3. Aini Y, Andari E. Analysis of service quality on patient satisfaction with treatment at the Puskesmas Pembantu Desa Pasir Utama. J Ilmiah Cano Ekonomos 2016;5: 81-88. (In Indonesia)

4. Akbar FH, Pasiga BH, Samad R, et al. Patient satisfaction levels in dental health care: a case study of people in North Mamuju, Indonesia 2017. J Dentomaxillofac Sci 2018;3: 115-118.

5. Laumara TT, Ahmad La-OAL, Paridah. Study on the utilization of dental polyclinic at Kapoiala Public Health Center, Kapoiala District, Konawe Regency, 2016. JIMKESMAS 2017;2: 1-11. (In Indonesia)

6. Meilasari W, Suwindere W, Polii H. Satisfaction level of adult patients in panoramic radiography services in the radiology installation of the maranatha Dental and Oral Hospital. Padjadjaran J Dent Res Student 2018;2: 87-94. (In Indonesia)

7. Mariane S, Henry O, Bernart SPH. Description of patient satisfaction levels on dental and oral care at the shoulder health center. J e-GiGi PAAI 2014;2: 1-11. (In Indonesia)

8. Zubir. Overview of the utilization of dental and oral health services based on knowledge and attitudes of patients at the Dental and Oral Hospital (RSGM) Banda Aceh. J Kesehatan Ilmiah Nasuwakes 2018;11: 79-86. (In Indonesia)

9. Akbar FH and Pratiwi R. Patient satisfaction against the quality of dental health services at Dental Polyclinic of Tenriawaru General Hospital in Bone Regency. J Dentomaxillofac Sci 2016;1: 177-184.

10. Siagian KV. Quality of public services and discipline of human resources at the BLU Dental and Oral Polyclinic of Prof. Dr. R. D. Kandou Manado. J e-GiGi PAAI 2016;4: 64-69.

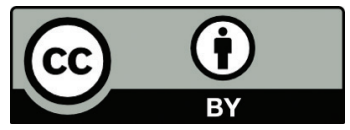

This work is licensed under a Creative Commons Attribution 